\title{
Youth unemployment in the EU15: regional and national inequalities throughout the 2008 economic crisis
}

\author{
Alberta M.C. Spreafico • Agnese Peruzzi • Enrica Chiappero-Martinetti* \\ Department of Political and Social Sciences, University of Pavia, Italy
}

Received: 28 July 2014

Revised: 19 September 2014

Accepted: 14 October 2014

\begin{abstract}
This paper analyses inequality in terms of youth unemployment rates across the EU15 regions and countries, before and throughout the 2008 Economic Crisis. A series of descriptive investigations explore intra-national regional inequalities, as well as cross-national ones. It is found that before the crisis, there were generalized low average levels of youth unemployment and inequality was mostly found within countries. Throughout the crisis, intra-national homogeneity and cross-national inequality increased. By 2013 a polarization dynamic emerged, with a Southern/Mediterranean European group of regions reaching acutely high levels of youth unemployment while a few countries were resilient to the crisis and Germany reduced its youth unemployment rates.
\end{abstract}

Keywords: youth unemployment, inequality, regional convergence, economic crisis JEL Classification Codes: E24, O47, R23

\section{Introduction}

Income and wealth still represent the metric most commonly used for measuring economic inequality of individuals and households. However, other evaluative spaces can be equally relevant and even more suitable when the attention is not addressed to the whole population but to specific target groups, such as youth. The Capability Approach (cf. Sen 1980, 1985, 1999), for instance, emphasizes the need to consider the real opportunities young people face along their personal and professional life in other domains including, amongst others, education, employment, health and autonomy. All these dimensions are path-dependent, produce long-run

*Corresponding author. E-mail: enrica.chiappero@unipv.it.

Citation: Spreafico, A.M.C. , Peruzzi, A. and Chiappero-Martinetti, E. (2014) Youth unemployment in the EU15: regional and national inequalities throughout the 2008 economic crisis, Economics and Business Letters, 3(3), 177190. 
consequences in the life trajectories of a young person and can heavily compromise one's ability to achieve a full human development (Hardgrove et al., 2014).

The need to address people's vulnerability to negative shocks is clearly shown by the impact that the recent economic crisis is having in terms of losses of opportunities. This holds true for all generations, but is especially alarmingly for young people who are experiencing some of the most profound hardships, in particular in the labour market sphere (ILO, 2012; O'Higgins, 2012; Marelli and Signorelli, 2011). Despite the relatively high investments in education for the younger generations, in almost all European countries young people are more exposed to vulnerable living conditions and precarious labour-market positions and have fewer opportunities compared to their parents (European Commission, 2013; Choudhry et al., 2012). In the Mediterranean countries of the EU, the youth unemployment rate ${ }^{1}$ is higher than the total unemployment rate (sometimes more than twice as high), it rises faster and the duration of youth unemployment is also steadily increasing becoming a persistent trait of these economies (Bruno et al., 2014).

The impact of the economic crisis on unemployment is the result of the interaction of multiple (structural, institutional and social) factors that can produce, reproduce and exacerbate differences in terms of circumstances and opportunities. As recent analyses on income and wealth distribution show, geographical location more than social background-is becoming a key determinant of inequality. In fact, in a recent long term analysis on global income inequality, Milanovic shows that even if many factors can contribute to determine individual income level, where people are born and reside seem to matter more in the today's world: "Around 1870, class explained more than $2 / 3$ of global inequality. And now? The proportions have exactly flipped: more than $2 / 3$ of total inequality is due to location that we, generally, acquire at birth" (Milanovic, 2012:19). The recent trends in youth unemployment rates in Europe also seem to show that location matters and therefore we want to analyse if even in a relatively homogenous context like EU-15, regional disparities can contribute to determine inequality of opportunity on the labour market for the younger generations.

The aim of this paper is therefore to analyse youth unemployment before and throughout the current economic crisis, exploring and comparing cross-national inequalities, as well as intranational regional ones with the aim of identifying similarities and differences across regional clusters and to investigate to what extent location (i.e. regional contexts) matters.

\section{Data and methods}

The analyses presented in this paper are carried out for a sample composed of the EU-15 countries and associated 82 regions $^{2}$, for a pre-crisis year (2007) and two subsequent years in order to explore intermediate (2011) and more recent (2013) effects of the on-going crisis, on the basis of the latest Eurostat data available.

The focus has been kept on the most consolidated and comparable nucleus of 15 European countries, also for reasons of data availability. However, remarkable differences are known to

\footnotetext{
${ }^{1}$ In this paper we utilize the standard Eurostat, Labour Force Surveys, definition of youth that refers to people aged 15 to 24 years old.

${ }^{2}$ Note that the NUTS level-1 regions of France include also Overseas Departments, "Départements d'Outre Mer". However, this region was not included in the analyses, it is not part of the sample of 82 regions under investigation. Please refer to Table I in the Appendix for a complete list of sampled countries and regions.
} 
persist even within this relatively homogenous group of countries, suggesting that a disaggregated regional perspective can contribute to better depict the differential impact of the economic crisis within and between contexts. Thus, NUTS-level data was utilized to better describe levels, trends and patterns of youth unemployment at the regional level.

First, a series of descriptive investigations are provided to explore between and within country inequalities in terms of youth unemployment rates and changes throughout the economic crisis. Further, an analysis of the standard deviation of inter-national and intra-national youth unemployment rates allows capturing changes $\sigma$-convergence at the country and European level. The notion of $\sigma$-convergence, typically measured by changes in the standard deviation of regional income per capita, has also been used for analyzing European cohesion (see for example, Sala-iMartin, 1996; Monfort, 2008). However, in this paper, the concept is redefined as the fall of dispersion in terms of youth unemployment rates, instead of per capita income, across regions within one country, or across countries within the EU15.

Next, $\beta$-convergence is also descriptively explored through the use of a two-way scatter plot, as done by Rodriguez-Pose (1999). Again, the concept of $\beta$-convergence, denoting a process whereby entities that were relatively disadvantaged improve faster than those that were relatively advantaged, determining a catching-up dynamic, is tailored to the study of youth unemployment and merely descriptively investigated. In this case, a relatively greater reduction in youth unemployment rates in the regions recording higher rates in 2007, determines a positive $\beta$ convergence. On the other hand, if the regions starting with relatively higher youth unemployment rates also have a higher growth-rate, $\beta$-convergence is not occurring.

The intention is to highlight intra-country and cross-country regional differences and similarities in youth unemployment rates relatively to the pre-crisis average and to identify patterns of performance and changes in inequality throughout the crisis. In addition, plotting changes in regional youth unemployment rates vis-à-vis the absolute initial level, we want to observe if a dynamic polarisation persists between best and worst performing regions.

\section{Main findings}

\subsection{The national and cross country picture}

From 2007 to 2011 youth unemployment in the EU15 increased by 5.7 percentage points reaching a value of 20.7 per cent; it raised further in the subsequent period, even if less so, finally recording a mean value of 22.8 per cent - see Table 1. However, this EU-wide perspective masks important differences and similarities both between countries (inter-nationally) as well as within countries (intra-nationally or inter-regionally).

From an inter-national or cross-country perspective, in 2007 the Netherlands recorded the lowest average youth unemployment rate across the EU15. Along with the latter, Denmark, Austria, Ireland, Germany and the U.K. positioned themselves under the EU15 average rate of $15 \%$. On the contrary, Luxemburg, Finland, Portugal, Spain, Belgium, Sweden and France ranged from having youth unemployment rates just over this macro-regional average rage to a maximum of five percentage points above it. Italy and Greece alone had slightly higher values: respectively of $20.3 \%$ and $22.9 \%$. Overall, in 2007 the youth unemployment rates were quite contained. 
Table 1. Absolute youth unemployment rate (YUR) and relative changes in YURs.

\begin{tabular}{|c|c|c|c|c|c|}
\hline Country & $\begin{array}{l}\text { YUR } 2007 \\
(\%)\end{array}$ & $\begin{array}{l}\begin{array}{l}\text { YUR } 2011 \\
(\%)\end{array} \\
\end{array}$ & $\begin{array}{l}\text { YUR } 2013 \\
(\%)\end{array}$ & $\begin{array}{l}\text { Relative delta } \\
2007-2011 \\
\end{array}$ & $\begin{array}{l}\text { Relative delta } \\
2011-2013 \\
\end{array}$ \\
\hline NL & 5.9 & 7.6 & 11.0 & 28.81 & 44.74 \\
\hline DK & 7.5 & 14.2 & 13.1 & 89.33 & -7.75 \\
\hline $\mathrm{AT}$ & 8.7 & 8.3 & 9.2 & -4.60 & 10.84 \\
\hline $\mathrm{IE}$ & 9.0 & 29.1 & 26.8 & 223.33 & -7.90 \\
\hline $\mathrm{DE}$ & 11.9 & 8.6 & 7.9 & -27.73 & -8.14 \\
\hline U.K. & 14.3 & 21.1 & 20.5 & 47.55 & -2.84 \\
\hline EU15 & 15.0 & 20.7 & 22.8 & 38.00 & 10.14 \\
\hline LU & 15.2 & 16.8 & 15.5 & 10.53 & -7.74 \\
\hline FI & 16.5 & 20.1 & 19.9 & 21.82 & -1.00 \\
\hline PT & 16.6 & 30.1 & 37.7 & 81.33 & 25.25 \\
\hline ES & 18.2 & 46.4 & 55.7 & 154.95 & 20.04 \\
\hline $\mathrm{BE}$ & 18.8 & 18.7 & 23.7 & -0.53 & 26.74 \\
\hline SE & 19.3 & 22.8 & 23.5 & 18.13 & 3.07 \\
\hline FR & 19.8 & 23.1 & 24.9 & 16.67 & 7.79 \\
\hline IT & 20.3 & 29.1 & 40.0 & 43.35 & 37.46 \\
\hline EL & 22.9 & 44.4 & 58.3 & 93.89 & 31.31 \\
\hline
\end{tabular}

Note: The countries are ranked in ascending order based on the absolute values of 2007.

Focusing on the changes in youth unemployment (Figure 1), throughout the economic crisis the EU15 scenario markedly changed in terms of youth unemployment rates. Overall, there has been a conspicuous macro-regional average rise in youth unemployment, although each country had a distinct path. Particularly noticeable was the polarization that emerged between a group of Mediterranean countries (Greece, Spain, Portugal and Italy, which recorded prominently rising youth unemployment rates) and Germany, which, conversely, progressively reduced its youth unemployment. Countries such as Austria, the Netherlands and Denmark managed to always keep their rates below the yearly EU15 average. Presumably, in time, diverse structural conditions unequally managed to respond to the crisis beyond the initially contingent effects. 
Figure 1. Changes in youth unemployment rates, 2007-2011 and 2011-2013

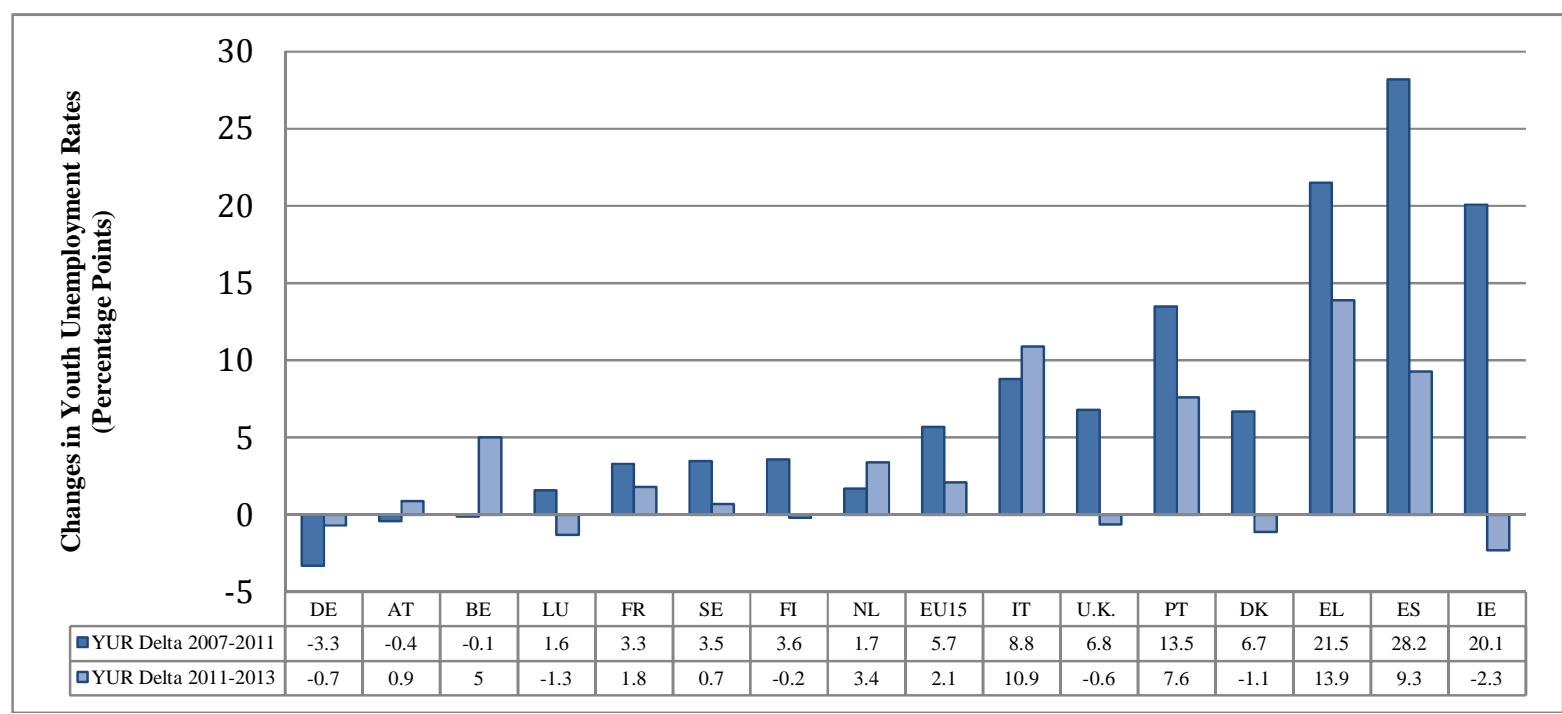

Notes: Changes in youth unemployment are measured in terms of differences in percentage points, reported on the $y$-axis. Graph is order in ascending order based on the data for the first period, 2007-2011.

Source: EUROSTAT, author's elaboration.

\subsection{The regional, intra-national and cross-country picture}

Analyses that are done exclusively at the European or national aggregate level can mask important within-country differences as well as cross-country similarities.

Table 2 illustrates the EU15 scenario in terms of regional patterns of youth unemployment rates. The ranges are fixed around the EU15 average of 2007, which was $15 \%$, so that changes relative to a pre-crisis scenario can be more markedly seen and across-time comparisons can be made relative to a stable benchmark. Also, the ranges were constructed to reveal: i) areas with below macro-regional average youth unemployment rates, ii) regions having rates equal to the EU15 average up to a maximum of five percentage points above it, iii) followed by those that record higher rates delimited in 10 percentage points increases up to 35 percentage points above the EU15 average of $15 \%$, and then iv) all those having rates above that, which means recording youth unemployment rates above $50 \%$.

The data reveals that before the crisis, $75 \%$ of regions either recorded below average youth unemployment rates ( 37 regions out of 82 ) or just up to 5 percentage points above it ( 25 out of 82). No regions recorded youth unemployment rates higher than 25 percentage points above the EU15 average. In contrast, with the crisis on going, a series of Mediterranean regions (from Spain and Greek in 2011, from Italy, Portugal, Spain and Greek in 2013) reached rates of over $50 \%$, meaning above 35 percentage points higher than the pre-crisis average value. Overall, it is evident (see Table 2) that there are plenty of intra-national differences as well as inter-national regional similarities, as most countries have regions positioning themselves in different rangegroups of youth unemployment rates together with regions from other nations. 
Table 2. Distribution of regions across ranges of YURs in 2007, 2011 and 2013 EU15 average in 2007, $15 \%=0$

\begin{tabular}{|c|c|c|}
\hline \multicolumn{3}{|l|}{2007} \\
\hline Range & All regions from the same country & Not all regions \\
\hline$<15 \%(-10-0)$ & NL, AT, DK, IE & UK, DE, IT, BE, PT, FR \\
\hline $15 \%<20 \%(0<5)$ & LU & UK, DE, IT, PT, FR, ES, SE, FI \\
\hline $20 \%<30 \%(5<15)$ & EL & DE, PT, SE, FR, ES, BE \\
\hline $30 \%<40 \%(15<25)$ & & IT, BE \\
\hline \multicolumn{3}{|l|}{$40 \%<50 \%(25<35)$} \\
\hline \multicolumn{3}{|l|}{$>50 \%(>35)$} \\
\hline $\begin{array}{l}\text { Total number of countries } \\
\text { represented }\end{array}$ & 6 & 9 \\
\hline \multicolumn{3}{|l|}{2011} \\
\hline Range & All regions from the same country & Not all regions \\
\hline$<15 \%(-10-0)$ & NL, AT & DE, DK, BE \\
\hline $15 \%<20 \%(0<5)$ & LU & DE, DK, UK, FR, IT \\
\hline $20 \%<30 \%(5<15)$ & SE & UK, FR, IT, BE, PT, IE, FI \\
\hline $30 \%<40 \%(15<25)$ & & FR, PT, IE, BE, ES, EL, IT \\
\hline $40 \%<50 \%(25<35)$ & & ES, EL, IT \\
\hline$>50 \%(>35)$ & & ES, EL \\
\hline $\begin{array}{l}\text { Total number of countries } \\
\text { represented }\end{array}$ & 4 & 11 \\
\hline \multicolumn{3}{|l|}{2013} \\
\hline Range & All regions from the same country & Not all regions \\
\hline$<15 \%(-10-0)$ & DE, AT, NL, DK & \\
\hline $15 \%<20 \%(0<5)$ & LU & UK, FR, BE, FI \\
\hline $20 \%<30 \%(5<15)$ & SE & UK, FR, IE, IT \\
\hline $30 \%<40 \%(15<25)$ & & FR, IE, IT, BE, PT \\
\hline $40 \%<50 \%(25<35)$ & & PT, EL, ES \\
\hline$>50 \%(>35)$ & & PT, IT, EL, ES \\
\hline $\begin{array}{l}\text { Total number of countries } \\
\text { represented }\end{array}$ & 6 & 9 \\
\hline
\end{tabular}

Notes: The ranges in brackets take the EU15 average for the year 2007, a value of $15 \%$, as the as the reference value so that EU15 average in $2007=0$.

In order to summarize and better understand the extent and patterns of intra-national crossregional convergence and divergence, as well as cross-country regional similarities, figure 2 illustrates regional dispersion for each EU15 country in 2007 and 2013. 
Figure 2. Regional dispersion in YURs, 2007 and 2013

2007

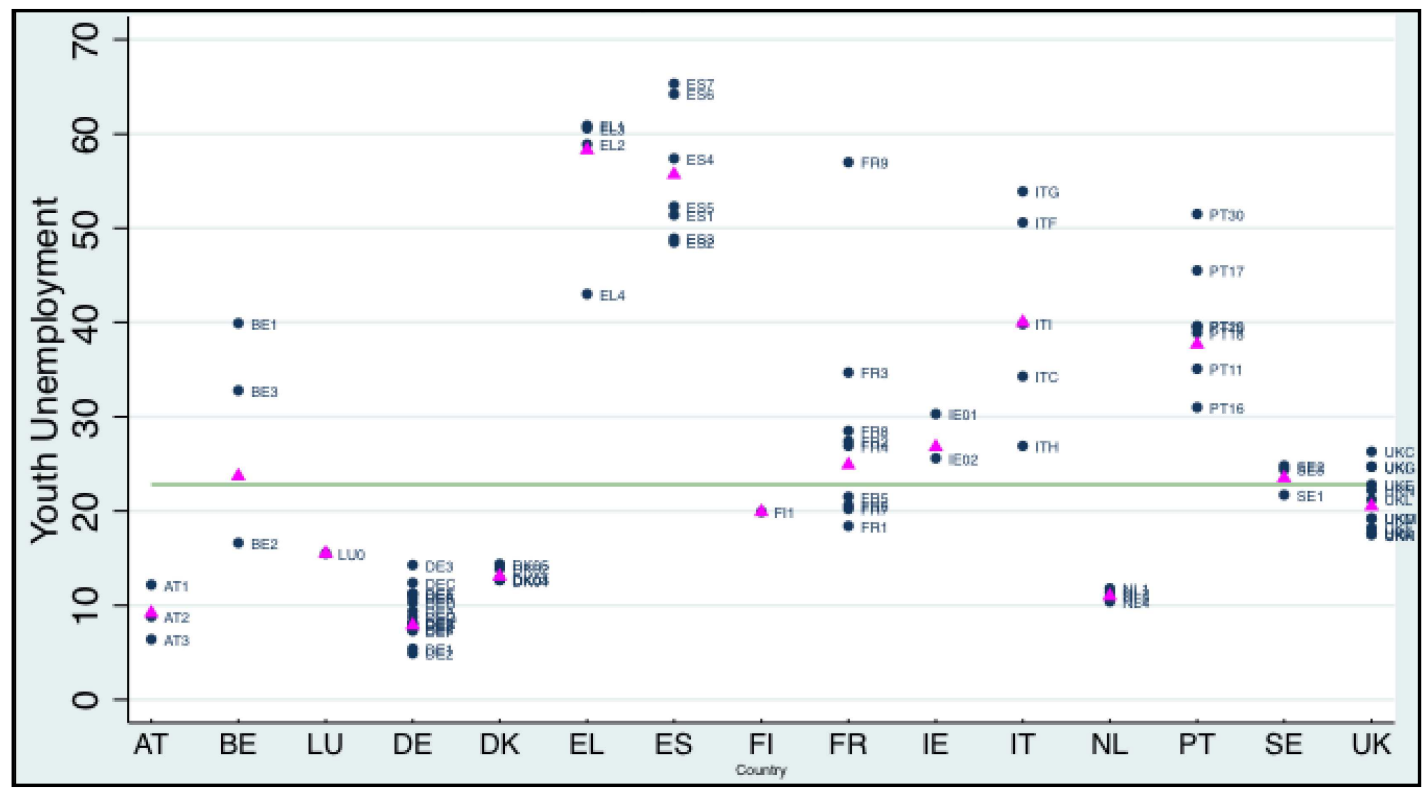

2013

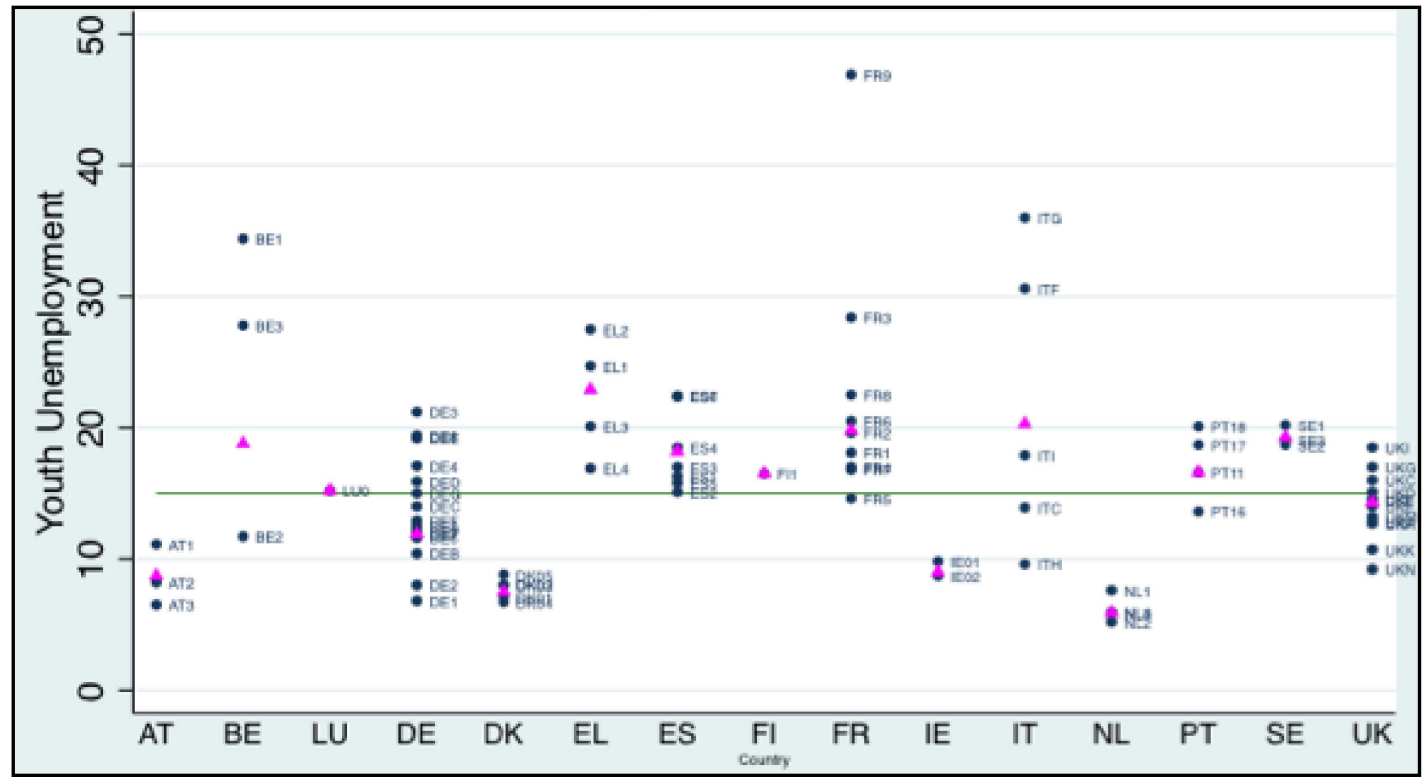

Notes: The green line represents the EU15 yearly average. The pink triangles represent the national averages. Data Source: EUROSTAT, authors' elaboration

Throughout the crisis, regional dispersion across the countries of the EU15 varied widely. The measurement of the standard deviation of intra-national youth unemployment rates (reported in Table A.1. of the appendix), indicative of a decrease of increase of $\sigma$-convergence, indicate that by 2013 the only two countries in which regional $\sigma$-convergence increased were Germany and the Netherlands. Conversely, $\sigma$-convergence decreased in Austria, Greece, Spain, France, Sweden, Ireland, Portugal and the U.K - although starting from and varying by very different extents. 
Italy, Belgium and Denmark had minimum changes in the extent of overall regional dispersion. Similarities across countries are also noteworthy. For example, certain regions of Greece, Spain, Italy and Portugal had very similar levels of youth unemployment - as possibly expected, since they belong to the Mediterranean countries particularly hard hit by the crisis.

Overall, at the European level, cross-national differences in youth unemployment rates increased throughout the crisis, thereby $\sigma$-convergence decreased in the EU15. Further, most countries that started off with lower rates kept performing better than those that began with higher rates, so that overall macro-regional $\beta$-convergence did not occur. Figure 3 , inspired by the works of Rodriguez-Pose (1999), summarizes these changes in national and cross-national convergence at the EU15 level.

Figure 3. Changes in youth unemployment, 2011-2013

(EU15 2013 averages represented by the green line)

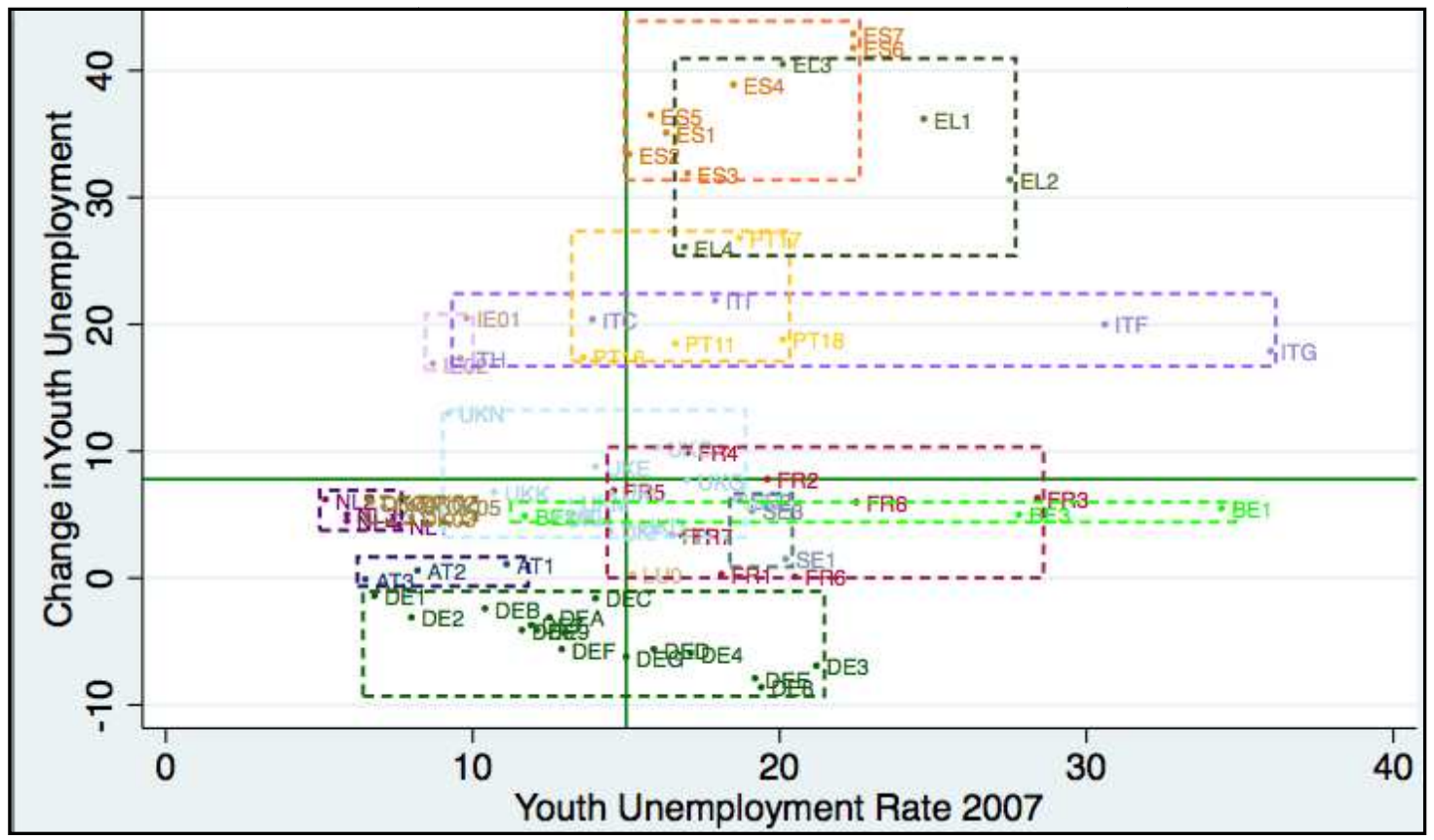

Source: Labour Force Surveys, 2011 and 2013. Author's elaboration.

The polarization of regions in the lower-left and upper-right quadrants of figure 3 is indicative of the fact that regions with youth unemployment rates below the pre-crisis EU15 average level in 2011 maintained this relative advantage or even registered improvements by 2013 - this is mostly the case of Germany, Austria, the Netherlands, Denmark and Luxemburg, but also of some regions from Belgium, the U.K. and France. On the contrary, the countries that had youth unemployment rates well-above the EU15 average before the crisis experienced an increase in youth unemployment. Overall, at the European level this is indicative of a lack of beta-convergence and of an increase of divergence.

The graph also reveals that some countries and regions, concentrated in the upper-left corner, started off with relatively low youth unemployment rates but increased them substantially, as is the case of Ireland. Conversely, in the bottom-right quadrant of the graph one can see the countries and regions that had relatively high pre-crisis youth unemployment rates but managed to contain or even reduce them are represented. These include former Eastern Germany, which decreased its 
regional youth unemployment rates, as well as regions from Sweden, France, Belgium and the U.K. which had contained increments, below the European average increase.

Finally, the "boxes" represented in Figure 3 give a broad idea of the levels of youth unemployment around which most regions belonging to a country tend to cluster (RodriguezPose, 1999). Both the presence of regional clustering within a country, as well as cross-national similarities are noticeable, as the majority of "boxes" comprising within-national regions overlap to some extent.

\section{Conclusion}

Where people live has traditionally been a key factor in determining individual living conditions. Today this is becoming increasingly relevant in order to understand the opportunities that young people have to participate in the labour market, due to the role played by regional contexts. The 2008 economic crisis hit regions differently in terms of youth unemployment, generating a differentiated picture at the European level.

This paper investigated youth unemployment within and across the countries of the EU-15 and the diversified impact of the 2008 economic crisis. Before the economic crisis youth unemployment was largely contained across the EU15, but it increased substantially throughout the crisis. A marked polarization occurred throughout the crisis between Germany on the one hand, which recorded continuously declining youth unemployment rates, and Spain, Greece, Portugal and Italy on the other, which experienced persistently rising rates. Between these two extremes, Ireland, Luxemburg, Denmark, Finland and the U.K. at first experienced rising youth unemployment rates but from 2011 managed to reverse this trend.

Most innovatively and importantly, the analyses presented in the paper also revealed significant within-country inter-regional differences and cross-country regional similarities in youth unemployment rates that are too often disregarded. For example, some regions within the Mediterranean countries have youth unemployment rates actually more in line with those recorded in Belgium or France. The results presented foster the need of further analyses and of policy-interventions able to carefully account for and target the regional contexts.

These investigations emphasize the fact that "one-size fit all policies", whether at the European or national level, are not the right solution for reducing youth unemployment rates. The presence of important regional differences within as well as similarities across countries, often not captured by mainstream analyses, suggest that interventions should be differentiated, contextualized and targeted even within countries - evermore so as the crisis exasperated withinnational labour market differentials in most countries. Further, the European cohesion policy cannot under-estimate the presence of these important regional inequalities in youth unemployment and the fact that the vast majority of most disadvantaged regions are not catching up to those performing better. Conversely, with the exception of Germany, a polarizing dynamic increased throughout the crisis both within and across countries, whereby the areas with relatively higher youth unemployment rates kept performing worse. This unequal distribution of labour market opportunities for young people should not be under-estimated as it can have cumulative effects, with some areas being increasingly "left behind".

In conclusion, the opportunities for young people to participate in the labour market decreased in absolute level throughout the crisis and became more unequally distributed across Europe. Revealing and understanding these within- and between-country specificities and similarities is fundamental in order to better shape, replicate and implement effective policies. The 
consequences of a prolonged unemployment, underemployment or inactivity can undermine people's autonomy and self-esteem and leave some youth permanently disadvantaged with a low income profile, poor job experience and lack of social protection in their adult and elderly life. Even in the (unlikely) case of a fast and sustained upturn it will take time to translate economic growth into stable and adequate jobs and livelihood opportunities with the obvious risk of producing what has been already labelled as a "lost generation".

Acknowledgements. The research leading to these results has received funding from the European Union's Seventh Framework Programme for research, technological development and demonstration under grant agreement n. 320136 (Project Title "Social Innovation - Empowering the Young for the Common Good", Project Acronym: SocIEtY). This article reflects the authors' views and the European Union is not liable for any use that may be made of the information contained within."

\section{References}

Bruno, G.S.F., Choudhry, M.T., Marelli, E. and Signorelli, M. (2014) Youth unemployment: key determinants and the impact of crises, in Miguel, G.S., Malo, A. and Sciulli, D. (eds.) Disadvantaged workers. Empirical evidence and labour policies, AIEL Series in Labour Economics, Springer, 121-148.

Choudhry, M.T., Marelli, E. and M. Signorelli (2012) Youth unemployment rate and impact of financial crises, International Journal of Manpower, 33(1), 76-95.

European Commission (2013) Employment and social developments in Europe 2013, DirectorateGeneral for Employment, Social Affairs and Inclusion, Bruxelles.

Hardgrove, A., Pells, K., Boyden, J. and Dornan, P. (2014) Youth vulnerabilities in life course transitions, Occasional Paper Human Development Report Office, UNDP, New York, NY (U.S.A.), https://infoeuropa.eurocid.pt/files/database/000047001000048000/000047547.pdf [Accessed: August 8, 2014].

ILO (2012) Global employment trends for youth, International Labour Office, Geneva

Marelli, E. and Signorelli, M. (2011) Youth unemployment before and after the crisis, in Manzella, P. and Ristico, L. (eds.) Productivity, investment in human capital and the challenge of youth employment, Cambridge Scholars, Newcastle Upon Tyne, U.K., 5784.

Milanovic, B. (2012) Global inequality by the numbers: in history and now, World Bank Policy Research Working Paper 6259.

Monfort, P. (2008) Convergence of EU regions: measures and evolution, European Commission, Regional Policy. [Online] Available from: O'Higgins N. (2012) This time it's different? Youth labour markets during 'the great recession', in Comparative Economic Studies, 3, 395-412.

O'Higgins, N. (2012) This time it's different? Youth labour markets during 'the great recession', Comparative Economic Studies, 3, 395-412.

Pirani, E. (2005) A multilevel approach to LC models: analysis of social exclusion among European regions, Ph.D. Thesis, University of Florence.

Rodríguez-Pose, A. (1999) Convergence or divergence? Types of regional responses to socioeconomic change, Tijdschrift voor Economische en Sociale Geografie, 90(4), 363-378. 
Sala-i-Martin, X. (1996) Regional cohesion: evidence and theories of regional growth and convergence, European Economic Review, 40(6), 1325-1352.

Sen, A. (1980) Equality of what?, in S. McMurrin (ed.) The Tanner lectures on human values, Salt Lake City, Utah.

Sen, A. (1984) Rights and capabilities, in A. Sen: Resources, Values and Development, Harvard University Press, Cambridge, MA., 307-325.

Sen, A. (1985) Commodities and capabilities, North Holland, Amsterdam.

Sen, A. (1999) Development as freedom, Knopf, New York. 


\section{Appendix}

Table A.1. National and regional yearly youth unemployment rates (YURs) and intra-national dispersion in terms of Standard Deviation (S.D.) $(2007,2011,2013)$

\begin{tabular}{|c|c|c|c|c|c|c|c|}
\hline Country & $\begin{array}{l}\text { YUR } \\
2007 \\
(\%) \\
\end{array}$ & $\begin{array}{l}\text { YUR } \\
2011 \\
(\%) \\
\end{array}$ & $\begin{array}{l}\text { YUR } \\
2013 \\
(\%) \\
\end{array}$ & $\begin{array}{l}\text { Regions \& Intra-National } \\
\text { Standard Deviation (S.D.) }\end{array}$ & $\begin{array}{l}\text { YUR } \\
2007 \\
(\%) \\
\end{array}$ & $\begin{array}{l}\text { YUR } \\
2011 \\
(\%) \\
\end{array}$ & $\begin{array}{l}\text { YUR } \\
2013 \\
(\%) \\
\end{array}$ \\
\hline Austria & 8.7 & 8.3 & 9.2 & $\begin{array}{l}\text { Ostösterreich } \\
\text { Südösterreich } \\
\text { Westösterreich } \\
\text { S.D. }\end{array}$ & $\begin{array}{l}11.1 \\
8.2 \\
6.5 \\
1.90\end{array}$ & $\begin{array}{l}11.9 \\
5.6 \\
6.3 \\
2.82\end{array}$ & $\begin{array}{l}12.2 \\
8.8 \\
6.4 \\
2.38\end{array}$ \\
\hline Belgium & 18.8 & 18.7 & 23.7 & $\begin{array}{l}\text { Région de Bruxelles-Capitale / } \\
\text { Brussels Hoofdstedelijk } \\
\text { Gewest } \\
\text { Vlaams Gewest } \\
\text { Région wallonne } \\
\text { S.D. }\end{array}$ & $\begin{array}{l}34.4 \\
11.7 \\
27.8 \\
9.53\end{array}$ & $\begin{array}{l}35.3 \\
12.7 \\
25.2 \\
9.24\end{array}$ & $\begin{array}{l}39.9 \\
16.6 \\
32.8 \\
9.75\end{array}$ \\
\hline Germany & 11.9 & 8.6 & 7.9 & $\begin{array}{l}\text { Baden-Württemberg } \\
\text { Bayern } \\
\text { Berlin } \\
\text { Brandenburg } \\
\text { Bremen } \\
\text { Hamburg } \\
\text { Hessen } \\
\text { Mecklenburg-Vorpommern } \\
\text { Niedersachsen } \\
\text { Nordrhein-Westfalen } \\
\text { Rheinland-Pfalz } \\
\text { Saarland } \\
\text { Sachsen } \\
\text { Sachsen-Anhalt } \\
\text { Schleswig-Holstein } \\
\text { Thüringen } \\
\text { S.D. }\end{array}$ & $\begin{array}{l}6.8 \\
8.0 \\
21.2 \\
17.1 \\
: \\
11.6 \\
11.9 \\
19.4 \\
12.1 \\
12.5 \\
10.4 \\
14.0 \\
15.9 \\
19.2 \\
12.9 \\
15.0 \\
4.00\end{array}$ & $\begin{array}{l}5.7 \\
5.4 \\
13.4 \\
12.5 \\
15.7 \\
6.8 \\
8.5 \\
10.5 \\
9.5 \\
9.8 \\
9.4 \\
10.3 \\
10.2 \\
14.0 \\
9.2 \\
8.2 \\
2.78\end{array}$ & $\begin{array}{l}5.4 \\
4.9 \\
14.3 \\
11.2 \\
: \\
7.5 \\
8.2 \\
10.8 \\
8.0 \\
9.4 \\
8.0 \\
12.4 \\
10.3 \\
11.3 \\
7.3 \\
8.8 \\
2.48\end{array}$ \\
\hline Greece & 22.9 & 44.4 & 58.3 & $\begin{array}{l}\text { Voreia Ellada } \\
\text { Kentriki Ellada } \\
\text { Attiki } \\
\text { Nisia Aigaiou, Kriti } \\
\text { S.D. }\end{array}$ & $\begin{array}{l}24.7 \\
27.5 \\
20.1 \\
16.9 \\
4.09 \\
\end{array}$ & $\begin{array}{l}50.4 \\
41.5 \\
43.2 \\
39.2 \\
4.19 \\
\end{array}$ & $\begin{array}{l}60.9 \\
58.9 \\
60.6 \\
43.0 \\
7.46 \\
\end{array}$ \\
\hline
\end{tabular}


Table A.1. National and regional yearly youth unemployment rates (YURs) and intra-national dispersion in terms of Standard Deviation (S.D.) $(2007,2011,2013)$ (cont.)

\begin{tabular}{|c|c|c|c|c|c|c|c|}
\hline Country & $\begin{array}{l}\text { YUR } \\
2007 \\
(\%) \\
\end{array}$ & $\begin{array}{l}\text { YUR } \\
2011 \\
(\%) \\
\end{array}$ & $\begin{array}{l}\text { YUR } \\
2013 \\
(\%) \\
\end{array}$ & $\begin{array}{l}\text { Regions \& Intra-National } \\
\text { Standard Deviation (S.D.) }\end{array}$ & $\begin{array}{l}\text { YUR } \\
2007 \\
(\%) \\
\end{array}$ & $\begin{array}{l}\text { YUR } \\
2011 \\
(\%) \\
\end{array}$ & $\begin{array}{l}\text { YUR } \\
2013 \\
(\%) \\
\end{array}$ \\
\hline Spain & 18.2 & 46.4 & 55.7 & $\begin{array}{l}\text { Noroeste (ES) } \\
\text { Noreste (ES) } \\
\text { Comunidad de Madrid } \\
\text { Centro (ES) } \\
\text { Este (ES) } \\
\text { Sur (ES) } \\
\text { Canarias (ES) } \\
\text { S.D. }\end{array}$ & $\begin{array}{l}16.3 \\
15.1 \\
17.0 \\
18.5 \\
15.8 \\
22.4 \\
22.4 \\
2.82\end{array}$ & $\begin{array}{l}40.3 \\
36.2 \\
41.1 \\
45.0 \\
46.8 \\
53.5 \\
50.8 \\
5.65\end{array}$ & $\begin{array}{l}51.4 \\
48.5 \\
48.9 \\
57.4 \\
52.3 \\
64.2 \\
65.3 \\
6.49\end{array}$ \\
\hline Finland & 16.5 & 20.1 & 19.9 & $\begin{array}{l}\text { Manner-Suomi } \\
\text { Åland } \\
\text { S.D. }\end{array}$ & $\begin{array}{l}16.5 \\
- \\
-\end{array}$ & $\begin{array}{l}20.1 \\
- \\
-\end{array}$ & $\begin{array}{l}19.9 \\
- \\
-\end{array}$ \\
\hline France & 19.8 & 23.1 & 24.9 & $\begin{array}{l}\text { Île de France } \\
\text { Bassin Parisien } \\
\text { Nord - Pas-de-Calais } \\
\text { Est (FR) } \\
\text { Ouest (FR) } \\
\text { Sud-Ouest (FR) } \\
\text { Centre-Est (FR) } \\
\text { Méditerranée } \\
\text { S.D. }\end{array}$ & $\begin{array}{l}18.1 \\
19.6 \\
28.4 \\
17.0 \\
14.6 \\
20.5 \\
16.8 \\
22.5 \\
4.01\end{array}$ & $\begin{array}{l}19.2 \\
23.1 \\
31.1 \\
20.6 \\
18.9 \\
23.2 \\
20.4 \\
24.9 \\
3.74\end{array}$ & $\begin{array}{l}18.4 \\
27.4 \\
34.7 \\
26.9 \\
21.5 \\
20.6 \\
20.2 \\
28.5 \\
5.17\end{array}$ \\
\hline Italy & 20.3 & 29.1 & 40.0 & $\begin{array}{l}\text { Nord-Ovest } \\
\text { Sud } \\
\text { Isole } \\
\text { Nord-Est } \\
\text { Centro (IT) } \\
\text { S.D. }\end{array}$ & $\begin{array}{l}13.9 \\
30.6 \\
36.0 \\
9.6 \\
17.9 \\
10.05\end{array}$ & $\begin{array}{l}22.2 \\
39.2 \\
42.7 \\
19.7 \\
28.9 \\
9.08\end{array}$ & $\begin{array}{l}34.3 \\
50.6 \\
53.9 \\
26.9 \\
39.8 \\
10.04\end{array}$ \\
\hline Luxembourg & 15.2 & 16.8 & 15.5 & $\begin{array}{l}\text { Luxembourg } \\
\text { S.D. }\end{array}$ & $\begin{array}{l}15.2 \\
-\end{array}$ & $\begin{array}{l}16.8 \\
-\end{array}$ & $\begin{array}{l}15.5 \\
-\end{array}$ \\
\hline Netherlands & 5.9 & 7.6 & 11.0 & $\begin{array}{l}\text { Noord-Nederland } \\
\text { Oost-Nederland } \\
\text { West-Nederland } \\
\text { Zuid-Nederland } \\
\text { S.D. }\end{array}$ & $\begin{array}{l}7.6 \\
5.2 \\
5.9 \\
5.9 \\
0.88\end{array}$ & $\begin{array}{l}8.8 \\
7.3 \\
7.8 \\
7.1 \\
0.66\end{array}$ & $\begin{array}{l}11.8 \\
11.4 \\
10.9 \\
10.4 \\
0.53\end{array}$ \\
\hline Sweden & 19.3 & 22.8 & 23.5 & $\begin{array}{l}\text { Östra Sverige } \\
\text { Södra Sverige } \\
\text { Norra Sverige } \\
\text { S.D. }\end{array}$ & $\begin{array}{l}20.2 \\
18.7 \\
19.1 \\
0.63\end{array}$ & $\begin{array}{l}21.5 \\
22.8 \\
25.6 \\
1.71\end{array}$ & $\begin{array}{l}21.7 \\
24.8 \\
24.4 \\
1.38\end{array}$ \\
\hline
\end{tabular}


Table A.1. National and regional yearly youth unemployment rates (YURs) and intra-national dispersion in terms of Standard Deviation (S.D.) $(2007,2011,2013)$ (cont.)

\begin{tabular}{|c|c|c|c|c|c|c|c|}
\hline Country & $\begin{array}{l}\text { YUR } \\
2007 \\
(\%) \\
\end{array}$ & $\begin{array}{l}\text { YUR } \\
2011 \\
(\%) \\
\end{array}$ & $\begin{array}{l}\text { YUR } \\
2013 \\
(\%) \\
\end{array}$ & $\begin{array}{l}\text { Regions \& Intra-National } \\
\text { Standard Deviation (S.D.) }\end{array}$ & $\begin{array}{l}\text { YUR } \\
2007 \\
(\%) \\
\end{array}$ & $\begin{array}{l}\text { YUR } \\
2011 \\
(\%) \\
\end{array}$ & $\begin{array}{l}\text { YUR } \\
2013 \\
(\%) \\
\end{array}$ \\
\hline U.K. & 14.3 & 21.1 & 20.5 & $\begin{array}{l}\text { North East (UK) } \\
\text { North West (UK) } \\
\text { Yorkshire and The Humber } \\
\text { East Midlands (UK) } \\
\text { West Midlands (UK) } \\
\text { East of England } \\
\text { London } \\
\text { South East (UK) } \\
\text { South West (UK) } \\
\text { Wales } \\
\text { Scotland } \\
\text { Northern Ireland (UK) } \\
\text { S.D. }\end{array}$ & $\begin{array}{l}16.0 \\
15.1 \\
14.0 \\
14.5 \\
17.0 \\
12.7 \\
18.5 \\
12.8 \\
10.7 \\
14.5 \\
13.2 \\
9.2 \\
2.46\end{array}$ & $\begin{array}{l}21.7 \\
23.9 \\
23.5 \\
20.7 \\
24.2 \\
17.7 \\
24.2 \\
16.1 \\
16.5 \\
25.2 \\
21.7 \\
19.5 \\
3.04\end{array}$ & $\begin{array}{l}26.3 \\
19.2 \\
22.8 \\
18.2 \\
24.7 \\
17.5 \\
24.7 \\
17.7 \\
17.5 \\
21.2 \\
19.2 \\
22.2 \\
3.03\end{array}$ \\
\hline Denmark & 7.5 & 14.2 & 13.1 & $\begin{array}{l}\text { Hovedstaden } \\
\text { Sjælland } \\
\text { Syddanmark } \\
\text { Midtjylland } \\
\text { Nordjylland } \\
\text { S.D. }\end{array}$ & $\begin{array}{l}7.1 \\
8.0 \\
8.0 \\
6.7 \\
8.8 \\
0.74\end{array}$ & $\begin{array}{l}15.4 \\
15.0 \\
14.2 \\
12.5 \\
13.9 \\
1.01\end{array}$ & $\begin{array}{l}12.7 \\
13.9 \\
12.8 \\
12.7 \\
14.4 \\
0.71\end{array}$ \\
\hline Ireland & 9.0 & 29.1 & 26.8 & $\begin{array}{l}\text { Border, Midland and Western } \\
\text { Southern and Eastern } \\
\text { S.D. }\end{array}$ & $\begin{array}{l}9.8 \\
8.7 \\
0.55\end{array}$ & $\begin{array}{l}32.8 \\
27.8 \\
2.5\end{array}$ & $\begin{array}{l}30.3 \\
25.6 \\
2.35\end{array}$ \\
\hline Portugal & 16.6 & 30.1 & 37.7 & $\begin{array}{l}\text { Norte } \\
\text { Algarve } \\
\text { Centro (PT) } \\
\text { Lisboa } \\
\text { Alentejo } \\
\text { Região Autónoma dos Açores } \\
\text { (PT) } \\
\text { Região Autónoma da Madeira } \\
\text { (PT) } \\
\text { S.D. }\end{array}$ & $\begin{array}{l}16.6 \\
- \\
13.6 \\
18.7 \\
20.1 \\
- \\
- \\
- \\
2.45\end{array}$ & $\begin{array}{l}28.5 \\
37.0 \\
26.3 \\
33.2 \\
32.2 \\
- \\
- \\
39.1 \\
4.45\end{array}$ & $\begin{array}{l}35.1 \\
39.5 \\
31.0 \\
45.5 \\
38.9 \\
\\
39.6 \\
51.5 \\
6.20\end{array}$ \\
\hline $\begin{array}{l}\text { Cross- } \\
\text { Country S.D. } \\
\text { (Percentage } \\
\text { Points) }\end{array}$ & 5.08 & 11.36 & 15.17 & & & & \\
\hline
\end{tabular}

